University of Nebraska - Lincoln

DigitalCommons@University of Nebraska - Lincoln

Publications from USDA-ARS / UNL Faculty

U.S. Department of Agriculture: Agricultural

Research Service, Lincoln, Nebraska

2012

Surfactant effects on soil aggregate tensile strength

Gary A. Lehrsch

USDA-ARS, gary.lehrsch@ars.usda.gov

R.E. Sojka

USDA-ARS

A.C. Koehn

USDA-ARS

Follow this and additional works at: https://digitalcommons.unl.edu/usdaarsfacpub

Lehrsch, Gary A.; Sojka, R.E.; and Koehn, A.C., "Surfactant effects on soil aggregate tensile strength" (2012). Publications from USDA-ARS / UNL Faculty. 1163.

https://digitalcommons.unl.edu/usdaarsfacpub/1163

This Article is brought to you for free and open access by the U.S. Department of Agriculture: Agricultural Research Service, Lincoln, Nebraska at DigitalCommons@University of Nebraska - Lincoln. It has been accepted for inclusion in Publications from USDA-ARS / UNL Faculty by an authorized administrator of DigitalCommons@University of Nebraska - Lincoln. 


\title{
Surfactant effects on soil aggregate tensile strength ${ }^{\text {i⿱ }}$
}

\author{
G.A. Lehrsch *, R.E. Sojka, A.C. Koehn \\ USDA-Agricultural Research Service, Northwest Irrigation and Soils Research Lab., 3793 N. 3600 E., Kimberly, ID 83341-5076, USA
}

\section{A R T I C L E I N F O}

\section{Article history:}

Received 21 September 2011

Received in revised form 1 June 2012

Accepted 17 June 2012

Available online 18 August 2012

\section{Keywords:}

Aggregate strength

Calcium

Kinetic energy

Particle bonding

Sprinkler irrigation

Wetting agent

\begin{abstract}
A B S T R A C T
Little is known regarding a soil aggregate's tensile strength response to surfactants that may be applied to alleviate soil water repellency. Two laboratory investigations were performed to determine surfactant effects on the tensile strength of 1) Ap horizons of nine wettable, agricultural soils collected from across the continental U.S., and 2) two of the nine soils (Latahco and Rad silt loams from the Pacific Northwest) that were sampled at two depths ( 5 and $15 \mathrm{~mm}$ ) after being sprinkler irrigated. Along with an untreated control, three surfactants (an alkyl polyglycoside, an ethylene oxide/propylene oxide block copolymer, and a blend of the two) were spray applied by hand at rates of $0,1,1.63,3.35,4.79$, or $8.14 \mathrm{~kg}$ active ingredient ha ${ }^{-1}$ to 1 ) air-dry, loose soil in Study 1 and 2) field-moist, tamped soil in Study 2 before being irrigated with surfactant-free water at $88 \mathrm{~mm} \mathrm{~h}^{-1}$ twice, once for $0.33 \mathrm{~h}$, then about $8 \mathrm{~d}$ later for $0.25 \mathrm{~h}$. Tensile strength was measured on oven-dry, 4 - to 6.35 -mm-diameter aggregates $(18 \leq n \leq 37)$ of known mass for each treatment using a load cell with an attached flat-tip probe moving at a constant $0.27-\mathrm{mm} \mathrm{s}^{-1}$ rate that applied continuous strain to each aggregate until it failed. In Study 1, tensile strength ranged widely, from $27 \mathrm{kPa}$ for Adkins loamy sand to $486 \mathrm{kPa}$ for Bolfar loam, averaged across surfactant treatments. Tensile strength for all nine surfactant-treated soils averaged $164 \mathrm{kPa}, 7 \%$ greater $(P=0.099)$ than the control. In Study 2 , surfactants significantly affected the tensile strength of Latahco but not Rad aggregates, when averaged across irrigations and sampling depths. After irrigation, aggregate tensile strength averaged $26 \%$ less $(P<0.001)$ at the 5- than 15-mm depth, likely due to droplet kinetic energy fracturing near-surface, intra-aggregate bonds or surfactant leaching. All told, tensile strength varied more by soil series and depth than by surfactants.
\end{abstract}

Published by Elsevier B.V.

\section{Introduction}

A major determinant of soil erosion, loss of tilth, and surface sealing is the structural failure of soil aggregates. The persistence and integrity of soil aggregates depend on their ability to retain their shape and strength when subjected to disruptive effects of transient stresses, such as tillage, raindrop or irrigation droplet kinetic energy, or the like (Rogowski et al., 1968; Watts et al., 1996). Crop sequences, management practices, fertility, drainage, soil conditioners, organic matter, irrigation, and water quality interact with aggregates to affect their size and strength (Abid and Lal, 2009; Horn and Peth, 2009; Tormena et al., 2008). Aggregate tensile strength, one of the most useful indicators of soil structural condition, is the stress, defined as the force acting per unit area, required to fracture interparticle bonds and cause aggregates to fail under tension when force is applied (Dexter and Kroesbergen, 1985; Horn and Dexter, 1989; Imhoff et al., 2002).

Soil aggregate tensile strength is important because it must be small enough for tillage to economically produce a friable seedbed,

\footnotetext{
Manufacturer or trade names are included for the readers' benefit. By including names, the USDA-ARS implies no endorsement, recommendation, or exclusion. USDA is an equal opportunity provider and employer.

* Corresponding author. Tel.: +1 208423 6508; fax: +1 2084236555.

E-mail address: Gary.Lehrsch@ars.usda.gov (G.A. Lehrsch).
}

yet great enough to support the weight of heavy equipment with minimal compaction (Błażejczak et al., 1995; Munkholm et al., 2002). Tensile strength is an important measure of 1 ) the quality of a seedbed created by tillage, and 2) a seedbed's condition after rainfall or irrigation (Kay et al., 1994). Tensile strength is also used to describe soil friability, defined by Utomo and Dexter (1981) as the tendency of a soil mass to crumble under applied stress. Utomo and Dexter (1981) quantified soil friability in terms of a scaling factor, $k$, that related tensile strength to aggregate size.

Aggregate strength is affected by a number of factors, especially wetting and drying. Tensile strength decreases rapidly as dry aggregates are hydrated (Dexter and Kroesbergen, 1985). As dry aggregates imbibe water due to matric potential gradients, air can be entrapped within them; associated stresses then form planes of weakness, particularly in soils that swell in a nonuniform manner (Watts and Dexter, 1998). Horn and Smucker (2005) noted that aggregate strength depends upon 1) swelling and shrinking processes, 2) the intensity, number, and timing of swelling and drying events, and 3) microbial activity with associated organic exudates. Czarnes et al. (2000) also reported that tensile strength was affected by plant growth, rooting, and organic exudates. Tensile strength increased with soil organic C and varied with depth (Guimaraes et al., 2009), increasing with depth in the study of Blanco-Canqui et al. (2005). Aggregate strength increases with soil clay content (Ben-Hur and Lado, 2008; Kemper et al., 1987), 
particularly when soils are dry (Barzegar et al., 1995). Blanco-Canqui et al. (2005) and Seguel and Horn (2006) reported that tensile strength increased with decreasing aggregate diameter. Similarly, Imhoff et al. (2002) found that the tensile strength of oxisols decreased with increasing aggregate volume.

Soil strength is dynamic; it changes temporally and spatially as soil water contents change due to precipitation, irrigation, evaporation, or plant uptake (Grant et al., 2001; Horn and Dexter, 1989; Reszkowska et al., 2011; Watts and Dexter, 1998). As soil dries, cementing agents such as soluble silica, $\mathrm{CaCO}_{3}$, or dispersed clay concentrate, then flocculate or precipitate at intra-aggregate contact points, increasing tensile strength (Dexter, 1988; Kay and Dexter, 1992; Kemper et al., 1987; Lehrsch et al., 1991, 1993). Calcium ions can also form bridges between organic colloids and clay surfaces that strengthen aggregates (Edwards and Bremner, 1967). Barzegar et al. (1994) also reported that $\mathrm{Ca}^{2+}$ increased the tensile strength of soils with much $\mathrm{Na}^{+}$, though for two of five Australian soils, strength was increased slightly more by $\mathrm{Mg}^{2+}$ than by $\mathrm{Ca}^{2+}$. Cation effects on tensile strength, however, are not fully understood. For example, on the remolded samples of Barzegar et al. (1994), strength was increased more by $\mathrm{Na}^{+}$than by either $\mathrm{Mg}^{2+}$ or $\mathrm{Ca}^{2+}$. Failure zones and cracks form more readily in surface than subsurface soil because surface soil undergoes more wetting and drying and, in temperate regions, freezing and thawing (Hershfield, 1974; Lehrsch et al., 1991; Watts and Dexter, 1998). Soil strength also changes spatially because surface and near-surface aggregates are more often pierced by plant roots than are subsurface aggregates (Watts and Dexter, 1998). Freezing and thawing decrease tensile strength temporally (Reszkowska et al., 2011).

A soil's wettability may increase with its base status (van't Woudt, 1959). Soluble $\mathrm{Ca}^{2+}$ has been implicated as being partly responsible for increased wetting of a subcritically water repellent soil, possibly by suppressing the double layer thicknesses of soil clays (Lehrsch and Sojka, 2011). Thinner diffuse double layers would lead in turn to clay flocculation and, with drying, an increase in soil strength.

Little is known regarding the relationship between tensile strength and soil water repellency. Since an increase in tillage (or disturbance) increases tensile strength (Abid and Lal, 2009; Munkholm et al., 2002; Reszkowska et al., 2011) but decreases soil water repellency (Bryant et al., 2007; Hallett et al., 2001; Lehrsch et al., 2011), tensile strength should be inversely proportional to soil water repellency. Indeed, data presented by Reszkowska et al. (2011) suggested a tendency for tensile strength to decrease as water repellency increased.

Surfactants (wetting agents) are known to decrease soil water repellency (Bially et al., 2005; Kostka, 2000). Not known, however, are surfactant effects upon soil aggregate tensile strength. Surfactants applied to production fields are commonly applied to both wettable and non-wettable soil areas because water repellency varies spatially (Doerr et al., 2000). Water repellency, though largely problematic for soil water management, does improve soil structure (Mataix-Solera and Doerr, 2004). Consequently, surfactants may or may not improve a soil's structural condition, with effects likely differing between water repellent and wettable soils, and from one soil to another (Lehrsch, in press; Lehrsch and Sojka, 2011; Lehrsch et al., 2011).

Therefore, the objective of Study 1 was to evaluate surfactant effects on the tensile strength of aggregates from nine wettable U.S. soils in agricultural production. The objective of Study 2 was to characterize the response of surfactant-treated aggregates at two depths to sprinkler irrigation. Study 1's objective was chosen, in part, to confirm and elaborate upon preliminary findings that suggested that 1 ) changes in a soil's aggregate strength depended upon surfactant properties, and 2) a particular surfactant did not affect the tensile strength of all soils similarly. Study 2's objective was chosen to further our knowledge of the strength of surfactant-treated aggregates when subjected to water droplet kinetic energy.

\section{Materials and methods}

\subsection{Surfactants and soils}

The research was conducted at the United States Department of Agriculture (USDA), Agricultural Research Service, Northwest Irrigation and Soils Research Laboratory, Kimberly, ID, USA. We studied three miscible, nonionic liquid surfactants manufactured by Aquatrols Corporation of America, Paulsboro, NJ. One surfactant was the commercially available IrrigAid Gold ${ }^{\circledR}$ (IGG) and a second was an ethylene oxide/propylene oxide block copolymer (COP) that made up approximately $60 \%$ of the $0.17 \mathrm{~kg}$ active ingredient $\mathrm{kg}^{-1}$ in IrrigAid Gold (Bially et al., 2005). The third surfactant, supplying the remaining $40 \%$ of IGG's active ingredient, was an alkyl polyglycoside (APG). The surfactant IGG as marketed has a $\mathrm{pH}$ of 6.4 and a specific gravity (SG) of $1.024 \mathrm{~kg} \mathrm{~L}^{-1}$, COP has a pH of 3.2 and SG of $1.043 \mathrm{~kg} \mathrm{~L}^{-1}$, and APG has a pH of 4.3 and SG of $1.149 \mathrm{~kg} \mathrm{~L}^{-1}$. Other properties of the surfactants were given by Lehrsch et al. (2011).

Nine soils from the continental U.S. were studied (Table 1). The soils represented a broad cross-section of many of those important to U.S. agriculture. Five major soil orders (Soil Survey Staff, 2010) were represented with textures ranging from loamy sand to silty clay loam. The soils' cropping histories and global positioning system coordinates where sampled were given by Lehrsch (in press). Properties of the soils' Ap horizons are given in Table 2. Particle size was determined using the pipette method (Gee and Or, 2002) and $\mathrm{pH}$ using a combination electrode in a 1:1 soil-water slurry (Thomas, 1996). Inorganic $\mathrm{C}$ was calculated from the $\mathrm{CaCO}_{3}$ equivalent, measured using the pressure-calcimeter method (Sherrod et al., 2002). Organic $C$ was calculated as the difference between inorganic $C$ and total $\mathrm{C}$, with the latter measured by the combustion of a 50-mg sample in a Thermo-Finnigan FlashEA1112 CNS analyzer (CE Elantech Inc., Lakewood, NJ). Cation exchange capacity (CEC) and clay mineralogy were obtained from the USDA Natural Resources Conservation Service Soil Characterization Database (National Cooperative Soil Survey, 2012), from published sources (Lewis et al., 1991; McDaniel and Hipple, 2010), or measured locally when possible. Gravimetric water contents at a matric potential of $-3 \mathrm{kPa}$ were measured using a pressure plate apparatus (Reynolds and Topp, 2007). The Wilhelmy plate method was used to measure the advancing contact angle (Lamparter et al., 2006).

Two studies were conducted. The first investigated surfactant effects on the tensile strength of nine U.S. soils. The second study, based in part upon the findings of the first, focused upon irrigated aggregate tensile strength responses with depth to surfactant applications. For the latter investigation, we used two of the earlier nine

Table 1

Soils studied.

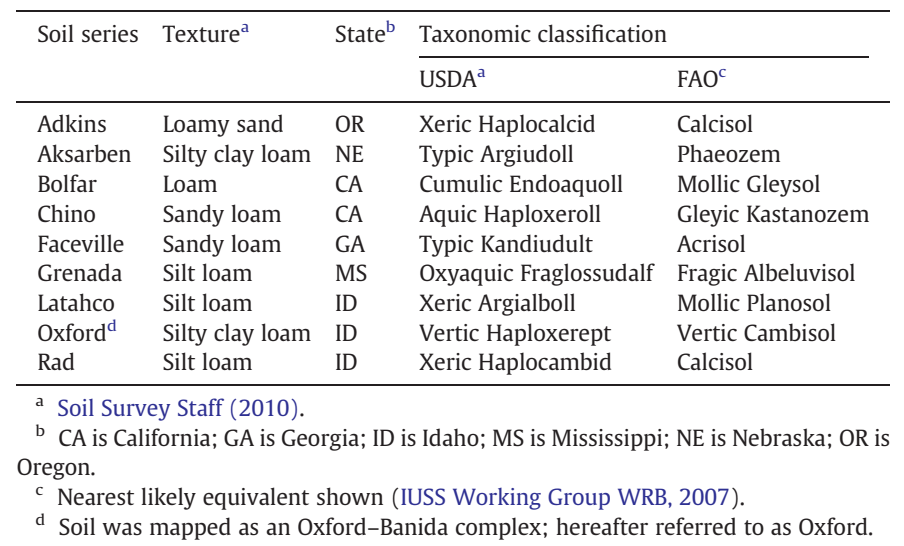


Table 2

Properties of the Ap horizon ${ }^{\mathrm{a}}$ of nine soils.

\begin{tabular}{|c|c|c|c|c|c|c|c|c|c|}
\hline Soil property & Adkins & Aksarben & Bolfar & Chino & Faceville & Grenada & Latahco & Oxford & Rad \\
\hline \multicolumn{10}{|l|}{ Particle size distribution, $\mathrm{g} \mathrm{kg}^{-1}$} \\
\hline Sand (0.05 to $2 \mathrm{~mm})$ & 840 & 50 & 340 & 610 & 750 & 70 & 90 & 180 & 250 \\
\hline Silt ( 0.002 to $0.05 \mathrm{~mm})$ & 110 & 610 & 400 & 270 & 80 & 740 & 650 & 430 & 610 \\
\hline Clay $(<0.002 \mathrm{~mm})$ & 50 & 340 & 260 & 120 & 170 & 190 & 260 & 390 & 140 \\
\hline $\mathrm{pH}(1: 1$, water $)$ & 6.3 & 6.3 & 6.8 & 7.8 & 6.3 & 4.7 & 5.5 & 6.8 & 7.8 \\
\hline Organic $\mathrm{C}, \mathrm{g} \mathrm{kg}^{-1}$ & 7.5 & 23.9 & 11.7 & 27.1 & 5.8 & 15.9 & 19.7 & 14.6 & 10.2 \\
\hline Inorganic $C, \mathrm{~g} \mathrm{~kg}^{-1}$ & 0.4 & 0.8 & 0.5 & 5.9 & 0.5 & 0.2 & 0.3 & 1.4 & 12.4 \\
\hline $\mathrm{CaCO}_{3}$ equivalent, $\mathrm{g} \mathrm{kg}^{-1}$ & 3.2 & 6.6 & 3.8 & 49.0 & 4.5 & 1.5 & 2.2 & 11.6 & 103.4 \\
\hline \multicolumn{10}{|l|}{ Cation exchange capacity } \\
\hline$(\mathrm{CEC}), \mathrm{cmol}(+) \mathrm{kg}^{-1}$ & 10.1 & 31.2 & 20.2 & 27.6 & 4.2 & 13.3 & 24.3 & $N A^{b}$ & 16.2 \\
\hline Water content at $-3 \mathrm{kPa}, \mathrm{kg} \mathrm{kg}^{-1}$ & 0.31 & 0.46 & 0.30 & 0.38 & 0.17 & 0.40 & 0.43 & 0.37 & 0.42 \\
\hline Advancing contact angle, degrees & 5.9 & 21 & 0 & 7 & 0 & 46 & 34 & 9.3 & 1.0 \\
\hline Dominant clay mineral $(s)^{c}$ & MT/MI & MT & NA & NA & KK & KK/MI/MT & MI & MI & IL \\
\hline
\end{tabular}

a Samples were collected from the surface to $0.10,0.15$, or $0.20 \mathrm{~m}$.

b NA is not available.

c IL is illite; KK is kaolinite; MI is mica; MT is montmorillonite.

soils for which surfactants increased water retention at high potentials (Lehrsch et al., 2011).

\subsection{Surfactant application rates}

In Study 1, both the COP and IGG surfactants were applied at IGG's recommended rate of $9.4 \mathrm{~L} \mathrm{ha}^{-1}$ of whole product (Table 3). Less active ingredient (a.i.) per unit area was applied with COP than IGG due to differences in a.i. proportion and in specific gravity. As mentioned above, COP supplied about $60 \%$ of IGG's active ingredient. Consequently, the a.i. application rate of COP was chosen to be ca. $60 \%$ of that of IGG in both studies (Table 3). On an a.i. per unit area basis, about five times as much surfactant was applied in Study 2 than 1. These rate differences gained us insight into surfactant rate effects on aggregate strength by comparing the findings of Study 2 with 1 for Latahco and Rad aggregates, the soils common to both studies.

\subsection{Study 1}

\subsubsection{Soil collection and handling}

In general, about $15 \mathrm{~kg}$ of each soil were collected by research collaborators from across the continent in 2008 or 2009 from the Ap horizon (uppermost $0.10 \mathrm{~m}$ in general; uppermost 0.15 or $0.20 \mathrm{~m}$ if necessary) of fields in agricultural production. After being collected, each of the field-moist soils was sealed in three, 19-L plastic buckets, then over-night mailed or transported to the laboratory at Kimberly. Upon arrival, each soil's gravimetric water content was measured. The field moist soils were then stored in air-tight containers at $4{ }^{\circ} \mathrm{C}$ until analyzed.

Table 3

Surfactant treatments, dilution factors, and application rates for Studies 1 and 2.

\begin{tabular}{|c|c|c|c|}
\hline \multirow[t]{2}{*}{ Surfactant treatment ${ }^{\mathrm{a}}$} & \multirow{2}{*}{$\begin{array}{l}\text { Dilution factor, } \\
\text { by wt. }\end{array}$} & \multicolumn{2}{|c|}{ Surfactant application rate } \\
\hline & & $\begin{array}{l}\text { Whole product } \\
\left(\mathrm{L} \mathrm{ha}^{-1}\right)\end{array}$ & $\begin{array}{l}\text { Active ingredient } \\
\left(\mathrm{kg} \mathrm{ha}^{-1}\right)\end{array}$ \\
\hline \multicolumn{4}{|l|}{ Study 1} \\
\hline Control & NA & 0 & 0 \\
\hline COP & $1: 8.75$ & 9.4 & 1.00 \\
\hline IGG & $1: 4$ & 9.4 & 1.63 \\
\hline \multicolumn{4}{|l|}{ Study 2} \\
\hline Control & NA & 0 & 0 \\
\hline APG & $1: 26.31$ & 4.17 & 3.35 \\
\hline $\mathrm{COP}$ & $1: 26.13$ & 4.59 & 4.79 \\
\hline IGG & 1:11.70 & 46.8 & 8.14 \\
\hline
\end{tabular}

${ }^{a}$ COP was an ethylene oxide/propylene oxide block copolymer; IGG was IrrigAid Gold $\circledast$; and APG was an alkyl polyglycoside. All surfactants are described in the text and were supplied by Aquatrols Corporation of America, Paulsboro, NJ.

\subsubsection{Surfactant application}

We assumed that the surfactant solution would wet the uppermost $10 \mathrm{~mm}$ of soil to which it was applied. The surfactant application rate, on an active ingredient per unit mass oven-dry soil basis, was then calculated based upon a 10-mm depth of treated field soil at a dry bulk density (BD) of 1) $1.1 \mathrm{Mg} \mathrm{m}^{-3}$ for soils with $<520 \mathrm{~g} \mathrm{~kg}^{-1}$ sand or 2) $1.4 \mathrm{Mg} \mathrm{m}^{-3}$ for sandier soils. The appropriate volume of IGG, then COP, was diluted with double deionized water (DDI) as needed so that the desired rate of the surfactant's a.i. would be applied with $70 \mathrm{ml}$ of its dilute solution. The DDI had a $\mathrm{pH}$ of 4.9 and electrical conductivity (EC) of $2.4 \times 10^{-3} \mathrm{dS} \mathrm{m}^{-1}$. The DDI's sodium adsorption ratio (SAR) was nil because $\mathrm{Na}^{+}$was not detected via inductively coupled plasma optical emission spectroscopy (ICP-OES) performed using an Optima Model 4300 DV spectrometer (Perkin Elmer Instruments, Waltham, MA). The dilute solutions' pH was 6.0 for IGG and 4.6 for COP.

Soil was first air-dried, then passed through an 8-mm sieve. An air-dry mass of $0.70 \mathrm{~kg}$ of sieved soil was placed on a $0.6-\mathrm{m} \times 0.6-\mathrm{m}$ piece of plastic sheeting and spread smoothly into an approximate 10-mm-thick, circular layer with a clean spatula moving horizontally. Approximately $15 \mathrm{ml}$ of the desired $70 \mathrm{ml}$ of dilute surfactant solution were uniformly sprayed by hand from a spray bottle onto the soil. The soil on the sheeting was then thoroughly mixed by repeatedly lifting alternate corners of the sheeting. The soil was then again spread on the sheeting using the spatula as before. This spraying and mixing protocol was repeated another 4 to 5 times until $70 \mathrm{ml}$ of dilute solution had been applied. Similarly, $70 \mathrm{ml}$ of surfactantfree, reverse-osmosis water (RW) was applied to the control. The RW had a $\mathrm{pH}$ of 5.7, EC of $7.2 \times 10^{-3} \mathrm{dS} \mathrm{m} \mathrm{m}^{-1}$, and SAR of $2.1\left(\text { meq } \mathrm{L}^{-1}\right)^{0.5}$. Other RW properties were given by Lehrsch and Sojka (2011). The solution volume applied was determined by repeated weighing of the spray bottle containing the surfactant solution. The soil sample was then representatively split into four pie piece-shaped lots, one of about $250 \mathrm{~g}$ for the soil aggregate tensile strength measurement and three other 150-g lots for an ancillary water stable aggregation measurement (Lehrsch, in press). Each of the treated soil samples and the control (still on the sheeting) were left undisturbed for $72 \mathrm{~h}$ to dry at ambient temperature (ca. $22{ }^{\circ} \mathrm{C}$ ) and relative humidity (ca. 26\%). Each of the now air-dry soil samples was stored in a sealed plastic bag without overburden pressure at $4{ }^{\circ} \mathrm{C}$ for no more than $150 \mathrm{~d}$ until analysis.

\subsubsection{Tensile strength measurements}

The treated soil was gently dry sieved by hand to obtain aggregates with diameters from 4.0 to $6.35 \mathrm{~mm}$. We studied aggregates of a relatively narrow size class to minimize known variation in aggregate strength with aggregate size (Seguel and Horn, 2006). Loamy aggregates with diameters from 2 to $8 \mathrm{~mm}$ are often near- 
spherical in shape, important when measuring tensile strength (Rogowski et al., 1968). Furthermore, 4- to 5-mm aggregates are important in seedbeds (Imhoff et al., 2002). The 4- to 6.35-mm aggregates were oven-dried at $105^{\circ} \mathrm{C}$ for $24 \mathrm{~h}$ before being analyzed. Dexter and Kroesbergen (1985) considered the oven-dried state a standard reproducible condition and recommended against measuring air-dried aggregates because small differences in aggregate water content significantly affected the compressive force at failure and consequently tensile strength. Immediately after removal from the drying oven, aggregates were placed in a desiccator containing dry silica gel to prevent any change in water content or potential, for $24 \mathrm{~h}$ or more.

An individual aggregate ( $26 \leq n \leq 37$, nominally 35$)$ from each treatment combination was then removed from the desiccator, weighed, then crushed. To measure tensile strength, we used a 5-mm-diameter, flat-tip probe attached to a calibrated load cell that, when in operation, continuously outputted voltage through a signal conditioner to a nearby computer. The load cell with its probe was moved by a computer-controlled stepping motor that lowered the tip at a constant rate of $0.27 \mathrm{~mm} \mathrm{~s}^{-1}$, thus applying continuous strain to the aggregate. The maximum voltage output prior to an aggregate's failure (i.e., the voltage inflection) was used with a calibration equation to determine that aggregate's polar compressive force at failure, $F(\mathrm{~N})$, calculated as:

$F=b g$

where $b$ was the load $(\mathrm{kg})$ determined from a calibration relating the load cell's conditioned voltage output to load and $g$ was the acceleration due to gravity (9.807 $\mathrm{m} \mathrm{s}^{-2}$ ) (Dexter and Kroesbergen, 1985).

We also determined each aggregate's effective spherical diameter, $D(\mathrm{~m})$ :

$D=d\left(\frac{m}{\bar{m}}\right)^{\frac{1}{3}}$

where $d=$ the mean of the upper and lower sieve apertures (i.e., $\left.5.175 \times 10^{-3} \mathrm{~m}\right), \mathrm{m}=$ the mass of the individual aggregate $(\mathrm{g})$, and $\bar{m}=$ the mean mass of the aggregate batch $(\mathrm{g})$ (Dexter and Kroesbergen, 1985). Eq. (2) adjusted $d$ to account for differences in the masses of individual aggregates, assuming that all aggregates had equal density (Dexter and Kroesbergen, 1985).

Tensile strength, TS (Pa), was then calculated as:

$T S=a\left(\frac{F}{D^{2}}\right)$

where $a$ was a unitless proportionality constant equal to $0.576, F$ was the compressive force at failure $(\mathrm{N})$, and $D$ was the aggregate's effective diameter $(\mathrm{m})$ (Dexter and Kroesbergen, 1985; Watts and Dexter, 1998). The constant $a$ was the ratio of tensile to compressive stress in the center of the aggregate (Perfect and Kay, 1994). Its value was based on the assumption of spherical form and perfect linearly elastic behavior (Dexter and Kroesbergen, 1985; Watts and Dexter, 1998). Dry soil best satisfies the assumption of perfect elasticity (Munkholm and Kay, 2002).

\subsection{Study 2}

\subsubsection{Soil collection and handling}

The Latahco and Rad silt loams (Tables 1 and 2) were collected in 2005 and 2006 and stored as described by Lehrsch et al. (2011). In brief, the Rad soil was collected at depths of 0 to $0.2 \mathrm{~m}$ from a fallow field $\left(42^{\circ} 31.08^{\prime} \mathrm{N}, 114^{\circ} 22.4^{\prime} \mathrm{W}\right)$ southwest of Kimberly, ID, while the Latahco was collected at the 0 - to $0.15-\mathrm{m}$ depth from a fallow area $\left(46^{\circ} 42.68^{\prime} \mathrm{N}, 117^{\circ} 00.21^{\prime} \mathrm{W}\right)$ south of Moscow, ID. After being transported to the research laboratory at Kimberly, the field-moist soil was stored at ambient temperature in covered metal bins.

A portion of each soil was retrieved from its metal bin and, being still field-moist, sieved through a $10-\mathrm{mm}$ screen into a $1.22-\mathrm{m}$ wide $\times 1.52-\mathrm{m}$ long $\times 0.20-\mathrm{m}$ deep steel box. Each box contained $76 \mathrm{~mm}$ of fine gravel underlayment and $76 \mathrm{~mm}$ of each soil, with the latter packed by tamping in 3 to 4 lifts to a nominal bulk density of $1.1 \mathrm{Mg} \mathrm{m}^{-3}$ (confirmed with subsequent measurements). After the soil surface was leveled with a screed, the upslope end of each box was elevated to position the soil surface at a $2.5 \%$ slope.

\subsubsection{Surfactant application, irrigations, and soil sampling}

The surfactants were applied to the packed soil in the boxes and the soil was then irrigated as described by Lehrsch et al. (2011). In brief, surfactant solutions were sprayed from a height of $0.36 \mathrm{~m}$ onto the soil surface using a 1.52-m-long spray boom equipped with five nozzles. By hand, we moved the boom at a calibrated rate twice across each box to evenly distribute the surfactant to the soil surface. The IGG's whole-product application rate was nominally $46.8 \mathrm{~L} \mathrm{ha}^{-1}$ mixed with well water (WW) per the dilution factors given in Table 3. The APG and COP surfactants were applied, on an a.i. per unit area basis, in proportion to their a.i. fraction in IGG (Table 3), also diluted with WW as necessary. The soil in each box then had $34.8 \mathrm{ml}$ of the appropriate surfactant solution sprayed onto it. The control spray solution was surfactant-free WW, drawn from the upper Snake River Plain aquifer in south-central Idaho. The WW had a pH of 7.6, EC of $0.7 \mathrm{dS} \mathrm{m} \mathrm{m}^{-1}$, and SAR of $1.7\left(\text { meq } \mathrm{L}^{-1}\right)^{0.5}$. Other WW properties were given by Lehrsch and Sojka (2011).

The first of two irrigations was performed within $2 \mathrm{~d}$ of surfactant application. A calibrated sprinkler simulator was used to irrigate the soil in each box with surfactant-free WW at a rate of $88 \mathrm{~mm} \mathrm{~h}^{-1}$ twice, once for $0.33 \mathrm{~h}$ and, about $8 \mathrm{~d}$ later, for $0.25 \mathrm{~h}$. The sprinkler simulator applied water with a median drop diameter of $1.2 \mathrm{~mm}$ and kinetic energy of $26.0 \mathrm{~J} \mathrm{~kg}^{-1}$ (Kincaid, 1996) to soils with antecedent water contents of ca. $0.10 \mathrm{~kg} \mathrm{~kg}^{-1}$. Runoff, with entrained sediment, was collected from the downslope edge of each box and has been reported elsewhere (Lehrsch et al., 2011). After being irrigated, soil in the boxes was subjected to forced air drying as box fans moved ambient warm air across soil surfaces. Since we did not want the sampling of wet soil to affect aggregate tensile strength, we dried the soil to a water content of ca. $0.11 \mathrm{~kg} \mathrm{~kg}^{-1}$, typically attained about $4 \mathrm{~d}$ after being irrigated. At that time, soil samples were collected by hand at depths from 0 to 10 and 10 to $20 \mathrm{~mm}$ from soil in each of the four quadrants of each box, then composited by depth. The composited samples were stored in vapor-proof polyethylene bags at $7^{\circ} \mathrm{C}$ for no more than $180 \mathrm{~d}$ before being analyzed. Additional soil was then returned to those portions of the soil surfaces disturbed by sampling. About $4 \mathrm{~d}$ after sampling, we irrigated the second time and thereafter collected soil samples adjacent to the previously sampled locations as we had done after the first irrigation for measuring tensile strength.

\subsubsection{Tensile strength measurements}

Each sample was gently dry sieved to obtain from 18 to 35 (usually 35 ) aggregates with diameters from 4 to $6.35 \mathrm{~mm}$. After being ovendried, each aggregate's tensile strength was measured as in Study 1.

\subsection{Statistical analysis}

To account for the great variability in tensile strength (BlancoCanqui et al., 2005), we analyzed multiple aggregates (usually 35) per sample, as is routinely done (Dexter and Kroesbergen, 1985; Imhoff et al., 2002; Reszkowska et al., 2011). To best estimate the mean strength for each replicate of our treatments, in accordance with the central limit theorem the strengths measured on each of the aggregates were arithmetically averaged (Horn and Dexter, 
1989; Johnson, 1988). The resulting values were the response variables subjected to subsequent statistical analyses.

The experimental design for Study 1 was a split plot with nine soils (Table 1) as main plots and three surfactant treatments (COP, IGG, and the Control, Table 3) as subplots, with three replications. The main plots were arranged in randomized complete blocks (RCBs). In the analysis of variance (ANOVA), the fixed effects were soils, surfactants, and soils $\times$ surfactants. Before performing the ANOVA, the tensile strength's error variance by treatment was examined using the relationship between its treatment means and corresponding treatment standard deviations (Box et al., 1978; Lehrsch and Sojka, 2011). To stabilize its error variance, we transformed the tensile strengths with a common (base 10) log before continuing the analysis. We then used a Bartlett's test and ANOVA grouping options as needed to ensure that all treatments had homogeneous variances.

Thereafter, the PROC Mixed procedure in SAS (SAS Institute Inc., 2009) was used to perform a mixed-model ANOVA with a significance probability $(P)$ of 0.05 , unless otherwise noted. For significant fixed effects, least-squares means were separated using the TukeyKramer test (Kramer, 1956). In the ANOVA, a single degree-offreedom contrast was used to compare both surfactants, as a group, with the control, averaged across soils. All means for Study 1 were back-transformed into original units for presentation. We also determined correlations between selected soil properties and tensile strength averaged across surfactant treatments by calculating Kendall's correlation coefficient, a nonparametric measure of association between two variables (SAS Institute Inc., 2009).

In Study 2, each soil was analyzed separately with the experimental design being a split split plot with four surfactant treatments (APG, COP, IGG, and the Control, Table 3 ) as main plots in RCBs, two irrigations as subplots in time, two sampling depths (5 and $15 \mathrm{~mm}$ ) as sub-subplots in space, and four blocks. Neither the Latahco nor the Rad tensile strength data required transformation. In each soil's ANOVA, three single degree-of-freedom contrasts were used, one to compare the effects of IGG with those of IGG's two components, as a group, averaged across irrigations and sampling depths, and two to make the same comparison at each sampling depth, averaged only across irrigations. All other data handling and statistical protocols were the same as for Study 1.

\section{Results and discussion}

\subsection{Study 1}

Tensile strength varied greatly from soil to soil (Fig. 1). For example, the tensile strength was more than 18 -fold greater for the Bolfar loam than the Adkins loamy sand, when averaged across the three surfactant treatments. The five-fold greater clay content of the Bolfar than Adkins soil (Table 2) likely led to more clay bridging within, and thus greater strength of, the Bolfar aggregates (Kay and Dexter, 1992; Kemper et al., 1987). Within a soil, the overlapping 95\% confidence intervals of the surfactants with the control revealed no outstanding surfactant effects on the tensile strength of any one of the nine soils (Fig. 1). Moreover, the effects of IGG and COP on each soil's tensile strength were statistically similar even though the properties of the two surfactants differed, as noted above.

With the exception of the coarse-textured Adkins, Chino, and Faceville soils, however, tensile strength tended to be greater for surfactant-treated than control aggregates of the remaining six soils (Fig. 1). Indeed, a pre-planned single degree-of-freedom comparison revealed (at $P=0.099$ ) that the tensile strength of surfactanttreated aggregates, $164 \mathrm{kPa}$, was $7 \%$ greater than the $153 \mathrm{kPa}$ of untreated aggregates, when all nine soils were considered a group. This strength increase in surfactant-treated soils may be a consequence of changes in water film thickness, diffusion, precipitation, and colloid movement. Surfactants applied to wettable soils increase water retention, likely by thickening water films, though confirmed only at high water potentials (Lehrsch et al., 2011). When applied in the present study, surfactants likely decreased the liquid-solid contact angle, eased water entry into pores (Letey, 2001), and thickened water films surrounding particles within aggregates. Slightly soluble inorganic bonding agents such as silica, $\mathrm{Ca}^{2+}$ (from the dissolution of $\mathrm{CaCO}_{3}$ or $\mathrm{CaSO}_{4}$ ) or, in soils from more humid locales, iron and aluminum oxides then diffused more easily and quickly from particle surfaces into the thicker water films deficient in those chemical agents covering the wettable soil surfaces (Tisdale and Nelson, 1975). Subsequent drying likely concentrated and precipitated the bonding agents at interparticle contact points (Kemper et al., 1987; Lehrsch et al., 1991, 1993) and, as drying continued, colloidal clay and clay domains were drawn to, then reoriented at those points (Kay and Dexter, 1992; Kemper et al., 1987), thus strengthening the surfactant-treated aggregates more than the control. Soil aggregates dried in an oven prior to measuring tensile strength attain water contents far less than any the aggregates might experience in the field. These water content differences make it difficult to predict a soil's response in the field based upon measured tensile strength responses of oven-dry aggregates (Munkholm and Kay, 2002). Nonetheless, drying in either an oven or the field would cause tensile strength to increase as soil water contents decrease, in general. Where the dilute solution of COP was applied, its relatively low $\mathrm{pH}$ of 4.6 likely led to increases in soil solution $\mathrm{Ca}^{2+}$ concentrations as $\mathrm{Ca}^{2+}$ ions were displaced from the exchange complex or were released from the dissolution of lime,

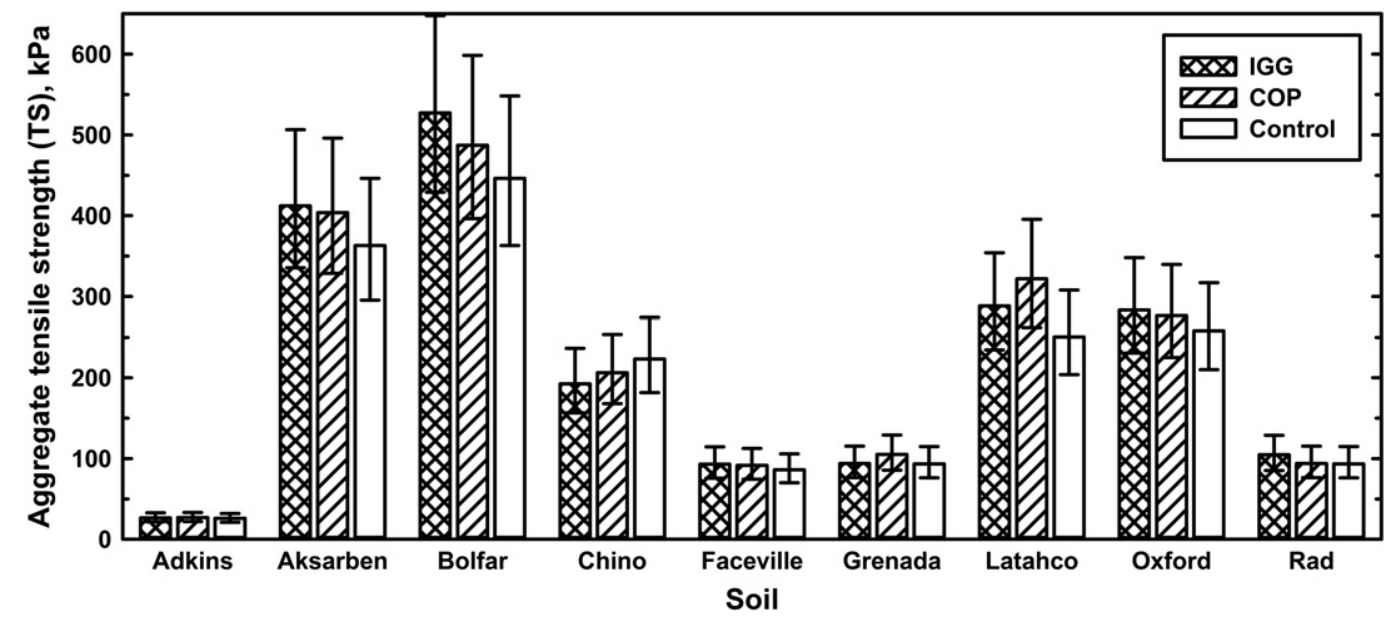

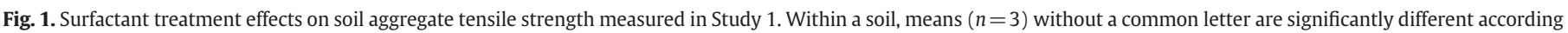
to the Tukey-Kramer test at $P=0.05$. Letters are not displayed if means did not differ. Means are shown with $95 \%$ confidence intervals. 
gypsum, or both. These surfactant-mediated increases in soil strength may help explain decreases in sediment loss from treated compared to untreated soil (Osborn et al., 1964). Management practices that increase tensile strength when a soil is dry generally increase strength when that soil wets, though exceptions occur at times (Munkholm and Kay, 2002). Clay migration and bridging appear particularly important since, compared to controls, surfactants tended to increase tensile strength the most in the Aksarben, Bolfar, Latahco, and Oxford soils (Fig. 1), the four soils with clay contents $\geq 260 \mathrm{~g} \mathrm{~kg}^{-1}$ (Table 2). The fact that the Adkins, Chino, and Faceville soils were the three sandiest soils that we studied (Table 2) suggests that surfactants may be less effective in increasing the tensile strength of coarsethan fine-textured soils. Compared to silty or clayey soils, sandy soils contain much larger primary particles and consequently have fewer interparticle contact points that could be strengthened when treated with surfactants.

Two opposing mechanisms may be affecting aggregate tensile strength in surfactant-treated soil. As noted above, surfactants increase water retention, at least at high potentials, likely by increasing water film thicknesses. All other factors being equal, greater water contents would decrease tensile strength but at the same time facilitate cementing agent movement to intra-aggregate contact points. If the treated soil were later to dry, those agents would precipitate or flocculate, likely increasing tensile strength.

A combination of soil properties may have acted in concert to affect aggregate tensile strength. Clay, organic matter, and polyvalent cations from the exchange complex may have formed clay-humic complexes that strengthened aggregates (Edwards and Bremner, 1967) and may have affected tensile strength responses to surfactants as well.

Since the soil $\times$ surfactant interaction was not significant $(P=$ 0.982 ), the tensile strength for each soil was averaged across surfactant treatments, then correlated with selected soil properties given in Table 2. For the nine soils we studied, tensile strength tended to be correlated with clay, sand, and organic $\mathrm{C}$ but not with total $\mathrm{C}$, $\mathrm{CaCO}_{3}$ equivalent, or contact angle (Table 4). The fact that tensile strength was positively correlated with clay, as found by Guérif (1990), Barzegar et al. (1995), and others, was likely due to clay bridging between intra-aggregate particles, as noted above. The negative correlation between tensile strength and sand [Kendall correlation coefficient $\left(r_{K}\right)=-0.50, P=0.061$ ] reflected the commonly observed inverse relationship between sand content and aggregation. This inverse relationship also reflects the lack of cohesion between sand grains within aggregates. This negative correlation coefficient supports the claim above that the surfactants least affected the tensile strength of coarse-textured soils. The positive correlation between tensile strength and organic $\mathrm{C}\left(r_{K}=+0.44, P=0.095\right)$ accords with the oft-noted increase in aggregate stability with soil organic $C$ (Tisdall and Oades, 1982). Dexter et al. (2008) recommended that the clay-to-organic $C$ ratio, as a measure of complexed organic $C$ (organic $\mathrm{C}$ bound to clay), be evaluated when predicting soil physical

\section{Table 4}

Correlations between selected soil properties and aggregate tensile strength, averaged across surfactant treatments.

\begin{tabular}{lllllll}
\hline \multirow{2}{*}{ Property } & \multicolumn{6}{l}{ Kendall correlation coefficient } \\
\cline { 2 - 7 } & $\begin{array}{l}\text { Tensile } \\
\text { strength }\end{array}$ & $\begin{array}{l}\text { Contact } \\
\text { angle }\end{array}$ & $\begin{array}{l}\mathrm{CaCO}_{3} \\
\text { equiv. }\end{array}$ & $\begin{array}{l}\text { Total } \\
\text { carbon }\end{array}$ & $\begin{array}{l}\text { Organic } \\
\text { carbon }\end{array}$ & Sand \\
\hline Clay & $+0.54^{*}$ & +0.11 & +0.03 & +0.03 & +0.25 & $-0.54^{*}$ \\
Sand & -0.50 & $-0.59^{*}$ & +0.11 & -0.39 & -0.50 & \\
Organic carbon & +0.44 & +0.42 & +0.06 & $+0.78^{* *}$ & & \\
Total carbon & +0.22 & +0.31 & +0.28 & & & \\
CaCO $_{3}$ equiv. & -0.06 & -0.37 & & & & \\
Contact angle & +0.20 & & & & & \\
\hline
\end{tabular}

* and ${ }^{* *}$ Significant at $P=0.05$ and 0.01 , respectively.

a $n=9$ in every case. properties. For the nine soils we studied, however, tensile strength was not correlated with the clay-to-organic $C$ ratio $\left(r_{K}=+0.17, P=\right.$ 0.532 ).

Of note is the significant correlation between contact angle and sand content $\left(r_{K}=-0.59, P=0.028\right)$ shown in Table 4 . Water repellent soils commonly exhibit contact angles $\geq 50^{\circ}$ (Shirtcliffe et al., 2006) and are most often coarse- rather than fine-textured (Doerr et al., 2000). These established relationships suggest that sand content should be directly proportional to contact angle for water repellent soils. However, for wettable soils as ours were (Table 2), the opposite appears true since contact angles decreased as sand content increased (Table 4). Differences in vegetation, its decomposition, or in the deposition of the resulting constituents account, at least in part, for these contact angle differences between wettable and non-wettable, coarse-textured soils (Doerr et al., 2000; Mataix-Solera and Doerr, 2004).

\subsection{Study 2}

As noted in Study 1, surfactant effects on tensile strength differed from soil to soil (Fig. 2). Surfactants altered tensile strength for the Latahco silt loam but not for the Rad silt loam, when strengths were averaged across irrigations and sampling depths. The surfactant means for the Latahco differed from one another in one case despite having overlapping confidence intervals (CIs). The CIs were wide because they included the variability of the random factors in the statistical model. Compared to the Rad, the Latahco had $86 \%$ more clay and nearly $100 \%$ more organic $C$ (Table 2 ), both of which were positively correlated with tensile strength (Table 4 ) and are commonly associated with better soil structure and more stable aggregates (Kay and Dexter, 1992; Tisdall and Oades, 1982). While not water repellent (Lehrsch et al., 2011), the Latahco did have a much greater contact angle than the Rad (Table 2), suggesting that surfactants may alter the wetting and water relations relatively more for soils similar to the Latahco than the Rad.

For the Latahco silt loam, tensile strength was $18 \%$ less $(P<0.009)$ for aggregates treated with IGG than COP (Fig. 2). As noted above, IGG was a blend of APG and COP. Thus, the lower tensile strength of IGG compared to COP must be due in large measure to the APG portion of IGG's constitution. Interestingly, the tensile strength of IGG-treated aggregates was not intermediate between those of APG-

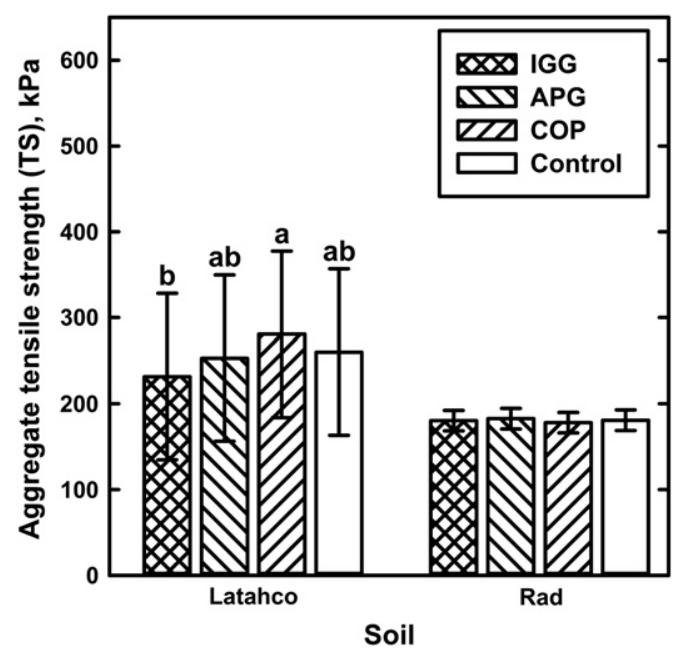

Fig. 2. Surfactant treatment effects on soil aggregate tensile strength for Latahco and Rad silt loams measured in Study 2. Data have been averaged across irrigations and sampling depths (interactions not significantly different, NS, at $P \geq 0.120$ ). Within a soil, means $(n=16)$ without a common letter are significantly different according to the Tukey-Kramer test at $P=0.05$. Letters are not displayed if means did not differ. Means are shown with $95 \%$ confidence intervals. 
and COP-treated aggregates but rather less, revealing an antagonistic effect of the blending of APG and COP upon aggregate strength (Fig. 2). Indeed, a single degree-of-freedom contrast confirmed that the tensile strength of Latahco aggregates treated with APG and COP (as a group), $267 \mathrm{kPa}$, was $15 \%$ greater $(P<0.008)$ than that of IGG-treated aggregates, averaged across irrigations and sampling depths. It should be noted that the a.i. application rates differed among the surfactants (Table 3). This antagonistic response occurred despite the facts that 1) COP provided proportionally more a.i. than APG to IGG (Table 3), and 2) COP tended to be more effective than APG in strengthening Latahco aggregates (Fig. 2). These differences among surfactants may be due to differences in the conformation or rearrangement of surfactant (or amphiphilic) molecules on particle surfaces upon oven-drying (Doerr et al., 2000; Lehrsch and Sojka, 2011).

Surfactant rate effects on aggregate strength were minimal, in general. Responses of Latahco and Rad aggregates to the nearly five-fold greater application rates in Study 2 (Fig. 2) than 1 (Fig. 1) were similar in most, but not all respects. For the Latahco, the tensile strength of aggregates treated with either IGG or COP was statistically similar to that of untreated aggregates. The Latahco's strength was greater for COP- than IGG-treated aggregates, though significantly so only in Study 2 (Fig. 2). For Rad aggregates, in contrast, tensile strength differed little among surfactant treatments in either study. The greater application rate, however, nearly doubled Rad's tensile strength from $97 \mathrm{kPa}$ in Study 1 to $180 \mathrm{kPa}$ in Study 2, when averaged across surfactant treatments. This doubling suggests that increasing surfactant application rates may increase the tensile strength of structurally unstable silt loams similar to the Rad (Lehrsch et al., 1991). The greater application rates in Study 2 vs. 1 may be enhancing the movement in Rad soil of cementing agents, particularly $\mathrm{Ca}^{2+}$ that upon drying can precipitate as $\mathrm{CaCO}_{3}$ to strengthen intra-aggregate bonds (Dexter, 1988). Additional research should be conducted, however, to confirm, at least for Rad silt loam, that tensile strength increases with surfactant application rates. Studies 1 and 2 differed, however, in more than surfactant application rates. For example, in Study 1 air-dry soil was sieved, then treated with surfactants while in Study 2 field-moist soil was sieved, treated with surfactants, then irrigated. Thus, differences in pretreatment, surfactant application rates, irrigation, or any combination of the three, may have been responsible for the differences in tensile strength from Study 1 to 2 .

For each soil in Study 2, single degree-of-freedom contrasts were used to compare, at each sampling depth, tensile strength of aggregates treated with IGG to a group treated with its two components, APG and COP. Averaged across irrigations, the strength of Latahco aggregates at the $5-\mathrm{mm}$ depth treated with IGG, $173 \mathrm{kPa}$, was one-fifth less (significant at $P=0.017$ ) than the 218 -kPa average of aggregates treated with its components (data not shown). For Latahco at the 15-mm depth, however, IGG's $290 \mathrm{kPa}$ did not differ from the components' average $316 \mathrm{kPa}$. For the Latahco soil, aggregates treated with IGG tended to be the weakest among all surfactant treatments (Fig. 2). In contrast with Latahco, Rad aggregate strength was similar whether treated with IGG or IGG's component group, at each depth (data not shown).

Each soil's tensile strength was less at the 5- than $15-\mathrm{mm}$ depth (Table 5). Compared to the $15-\mathrm{mm}$ depth, tensile strength at the $5-\mathrm{mm}$ depth was $31 \%$ less for the Latahco and $21 \%$ less for the Rad (both significant at $P<0.001$ ), when averaged across surfactant treatments and irrigations. Kay et al. (1994) attributed an increase in tensile strength with depth to more moderate water content changes (that is, wetting and drying) at depth than at the soil surface. In addition to smaller water content changes at depth than nearer the surface, two other mechanisms may have contributed to an increase in strength with depth in Study 2. First, surfactant molecules adhering to fine particulate organic matter or soil colloids may have been leached to lower depths by surfactant-free irrigation water (Lehrsch and Sojka, 2011; Miller et al., 1975). Recalling that aggregates from

\section{Table 5}

Depth effects on the tensile strength of Latahco and Rad silt loams in Study 2. Data for each soil have been averaged across surfactant treatments and irrigations (interactions not significantly different, NS, at $P \geq 0.121$ ).

\begin{tabular}{llc}
\hline \multirow{2}{*}{ Depth $(\mathrm{mm})$} & \multicolumn{2}{l}{ Tensile strength $(\mathrm{kPa})$} \\
\cline { 2 - 3 } & Latahco & Rad \\
\hline 5 & $210 \mathrm{y}^{\mathrm{a}}$ & $159 \mathrm{y}$ \\
15 & $303 \mathrm{x}$ & $202 \mathrm{x}$ \\
\hline a Within a column, means $(n=32)$ not followed by a common letter are significantly \\
different according to the Tukey-Kramer test at $P=0.05$.
\end{tabular}

Study 1 tended to be stronger where surfactant-treated, this leaching could account for weaker aggregates near the surface and stronger ones below. This process could explain the strength increase with depth but only where surfactants were applied. A second mechanism may have been a consequence of irrigation water droplet impact. In Study 2, the average 26\% smaller tensile strength near the surface compared to the subsurface (Table 5) could have been due to sprinkler droplet kinetic energy fracturing a portion of the intra-aggregate, particle-to-particle bonds, thus weakening near-surface aggregates while having little or no effect on aggregates deeper in the profile (Lehrsch and Kincaid, 2006).

\section{Conclusions}

1) Surfactants increased tensile strength by $7 \%$, compared to the control, when the responses of nine wettable agricultural soils were averaged.

2) When soils were considered individually, however, tensile strength was seldom affected by surfactants. Moreover, surfactant effects on tensile strength were not consistent from one soil to another.

3) Tensile strength varied greatly from soil to soil, tending to be greater for soils higher in clay and organic $\mathrm{C}$ but less for soils higher in sand, regardless of surfactant treatment.

4) Aggregate tensile strength was $26 \%$ less at the 5 - than $15-\mathrm{mm}$ depth, likely a consequence of surface and near-surface, intra-aggregate bonds being fractured by water drop kinetic energy, leaching of applied surfactant, or both.

5) Tensile strength varied more by soil series and depth than by surfactants.

\section{Acknowledgments}

Appreciation is extended to Dr. Don Horneck, Oregon State Univ., Hermiston, and to Dr. Paul McDaniel, Univ. of Idaho, Moscow, for assistance in locating needed soils. The authors also thank Dr. McDaniel for helping to classify soils in the FAO system. The gracious Mr. Ken Vandewaal, Boardman, OR, provided us the Quincy soil. Appreciation is also due to Dr. John Gilley, Lincoln, NE, Dr. Don Horneck, Hermiston, OR, Dr. Russell Nuti, Dawson, GA, Mr. Matt Quist, Atascadero, CA, Dr. Fred Rhoton, Oxford, MS, and Mr. Troy Winward, Kimberly, ID, for sampling, then shipping or transporting soils to Kimberly, and to Dr. Dave Bjorneberg for providing personnel for logistical support when needed. The authors also thank Dr. Jim Ippolito for the ICP-OES analyses and J. A. Foerster, J. L. Reed, and L. Romer-Keele for logistical support. The authors acknowledge financial and material support kindly provided by Aquatrols Corporation of America, Paulsboro, NJ. In addition, Aquatrols personnel kindly measured contact angles.

\section{References}

Abid, M., Lal, R., 2009. Tillage and drainage impact on soil quality: II. Tensile strength of aggregates, moisture retention and water infiltration. Soil and Tillage Research 103 (2), 364-372. 
Barzegar, A.R., Murray, R.S., Churchman, G.J., Rengasamy, P., 1994. The strength of remoulded soils as affected by exchangeable cations and dispersible clay. Australian Journal of Soil Research 32 (2), 185-199.

Barzegar, A.R., Oades, J.M., Rengasamy, P., Murray, R.S., 1995. Tensile strength of dry, remoulded soils as affected by properties of the clay fraction. Geoderma 65 (1-2), 93-108

Ben-Hur, M., Lado, M., 2008. Effect of soil wetting conditions on seal formation, runoff, and soil loss in arid and semiarid soils-a review. Australian Journal of Soil Research 46 (3), 191-202.

Bially, P.T., Kostka, S.J., Buckman, R.C., 2005. Improving the infiltration of water through repellent soils using synergistic surfactant blends based on alkyl glucosides and ethylene oxide-propylene oxide block copolymers. Journal of ASTM International 2 (10), 341-349.

Blanco-Canqui, H., Lal, R., Owens, L.B., Post, W.M., Izaurralde, R.C., 2005. Mechanical properties and organic carbon of soil aggregates in the northern Appalachians. Soil Science Society of America Journal 69 (5), 1472-1481.

Błażejczak, D., Horn, R., Pytka, J., 1995. Soil tensile strength as affected by time, water content and bulk density. International Agrophysics 9 (3), 179-188.

Box, G.E.P., Hunter, W.G., Hunter, J.S., 1978. Statistics for Experimenters: An Introduction to Design, Data Analysis, and Model Building. John Wiley \& Sons, Inc., New York, NY.

Bryant, R., Doerr, S.H., Hunt, G., Conan, S., 2007. Effects of compaction on soil surface water repellency. Soil Use and Management 23 (3), 238-244.

Czarnes, S., Dexter, A.R., Bartoli, F., 2000. Wetting and drying cycles in the maize rhizosphere under controlled conditions. Mechanics of the root-adhering soil. Plant and Soil 221 (2), 253-271.

Dexter, A.R., 1988. Advances in characterization of soil structure. Soil and Tillage Research 11, 199-238.

Dexter, A.R., Kroesbergen, B., 1985. Methodology for determination of tensile strength of soil aggregates. Journal of Agricultural Engineering Research 31 (2), 139-147.

Dexter, A.R., Richard, G., Arrouays, D., Czyż, E.A., Jolivet, C., Duval, O., 2008. Complexed organic matter controls soil physical properties. Geoderma 144 (3-4), 620-627.

Doerr, S.H., Shakesby, R.A., Walsh, R.P.D., 2000. Soil water repellency: its causes, characteristics and hydro-geomorphological significance. Earth-Science Reviews 51 (1-4), 33-65.

Edwards, A.P., Bremner, J.M., 1967. Microaggregates in soils. Journal of Soil Science 18, 64-73.

Gee, G.W., Or, D., 2002. Particle-size analysis. In: Dane, J.H., Topp, G.C. (Eds.), Methods of Soil Analysis, Part 4. Physical Methods. SSSA Book Ser. 5. Soil Science Society of America, Madison, WI, pp. 255-293.

Grant, C.D., Angers, D.A., Murray, R.S., Chantigny, M.H., Hasanah, U., 2001. On the nature of soil aggregate coalescence in an irrigated swelling clay. Australian Journal of Soil Research 39 (3), 565-575.

Guérif, J., 1990. Factors influencing compaction-induced increases in soil strength. Soil and Tillage Research 16 (1-2), 167-178.

Guimaraes, R.M.L., Tormena, C.A., Alves, S.J., Fidalski, J., Blainski, E., 2009. Tensile strength, friability and organic carbon in an oxisol under a crop-livestock system (in Portuguese). Scientia Agricola 66 (4), 499-505.

Hallett, P.D., Baumgartl, T., Young, I.M., 2001. Subcritical water repellency of aggregates from a range of soil management practices. Soil Science Society of America Journal 65 (1), 184-190.

Hershfield, D.M., 1974. Frequency of freeze-thaw cycles. Journal of Applied Meteorology 13 (3), 348-354.

Horn, R., Dexter, A.R., 1989. Dynamics of soil aggregation in an irrigated desert loess. Soil and Tillage Research 13 (3), 253-266.

Horn, R., Peth, S., 2009. Soil structure formation and management effects on gas emission. Biologia 64 (3), 449-453.

Horn, R., Smucker, A., 2005. Structure formation and its consequences for gas and water transport in unsaturated arable and forest soils. Soil and Tillage Research 82 (1), 5-14.

Imhoff, S., da Silva, A.P., Dexter, A., 2002. Factors contributing to the tensile strength and friability of Oxisols. Soil Science Society of America Journal 66 (5), 1656-1661.

IUSS Working Group WRB, 2007. World reference base for soil resources 2006, first update 2007. World Soil Resources Report No. 103. FAO, Rome. (Available at http:// www.fao.org/fileadmin/templates/nr/images/resources/pdf_documents/ wrb2007_red.pdf (accessed 21 Mar. 2011; verified 14 May 2012)).

Johnson, R.R., 1988. Elementary Statistics, 5th ed. PWS-Kent Publ. Co., Boston.

Kay, B.D., Dexter, A.R., 1992. The influence of dispersible clay and wetting/drying cycles on the tensile strength of a red-brown earth. Australian Journal of Soil Research 30 (3), 297-310.

Kay, B.D., Dexter, A.R., Rasiah, V., Grant, C.D., 1994. Weather, cropping practices and sampling depth effects on tensile strength and aggregate stability. Soil and Tillage Research 32 (2-3), 135-148.

Kemper, W.D., Rosenau, R.C., Dexter, A.R., 1987. Cohesion development in disrupted soils as affected by clay and organic matter content and temperature. Soil Science Society of America Journal 51 (4), 860-867.

Kincaid, D.C., 1996. Spraydrop kinetic energy from irrigation sprinklers. Transactions of the American Society of Agricultural Engineers 39 (3), 847-853.

Kostka, S.J., 2000. Amelioration of water repellency in highly managed soils and the enhancement of turfgrass performance through the systematic application of surfactants. Journal of Hydrology 231-232, 359-368.

Kramer, C.Y., 1956. Extension of multiple range tests to group means with unequal numbers of replications. Biometrics 12, 307-310.

Lamparter, A., Deurer, M., Bachmann, J., Duijnisveld, W.H.M., 2006. Effect of subcritical hydrophobicity in a sandy soil on water infiltration and mobile water content. Journal of Plant Nutrition and Soil Science 169 (1), 38-46.
Lehrsch, G.A., in press. Surfactant effects on the water-stable aggregation of wettable soils from the continental U.S. Hydrological Processes. http://dx.doi.org/10.1002/ hyp.9320.

Lehrsch, G.A., Kincaid, D.C., 2006. Sprinkler droplet energy effects on soil penetration resistance and aggregate stability and size distribution. Soil Science 171 (6), 435-447.

Lehrsch, G.A., Sojka, R.E., 2011. Water quality and surfactant effects on the water repellency of a sandy soil. Journal of Hydrology 403 (1-2), 58-65.

Lehrsch, G.A., Sojka, R.E., Carter, D.L., Jolley, P.M., 1991. Freezing effects on aggregate stability affected by texture, mineralogy, and organic matter. Soil Science Society of America Journal 55 (5), 1401-1406.

Lehrsch, G.A., Sojka, R.E., Jolley, P.M., 1993. Freezing effects on aggregate stability of soils amended with lime and gypsum. In: Poesen, J.W.A., Nearing, M.A. (Eds.) Soil Surface Sealing and Crusting. Catena Verlag, Cremlingen-Destedt, W. Germany, pp. 115-127.

Lehrsch, G.A., Sojka, R.E., Reed, J.L., Henderson, R.A., Kostka, S.J., 2011. Surfactant and irrigation effects on wettable soils: runoff, erosion, and water retention responses. Hydrological Processes 25 (5), 766-777.

Letey, J., 2001. Causes and consequences of fire-induced soil water repellency. Hydrological Processes 15 (15), 2867-2875.

Lewis, G.C., Fosberg, M.A., McDole, R.E., 1991. Characteristics of southern Idaho loess deposits and their relationship to soil fertility and management. Idaho Exp. Stn. Res. Bull., 151. Univ. of Idaho, Moscow.

Mataix-Solera, J., Doerr, S.H., 2004. Hydrophobicity and aggregate stability in calcareous topsoils from fire-affected pine forests in southeastern Spain. Geoderma 118 (1-2), 77-88.

McDaniel, P.A., Hipple, K.W., 2010. Mineralogy of loess and volcanic ash eolian mantles in Pacific Northwest (USA) landscapes. Geoderma 154 (3-4), 438-446.

Miller, W.W., Valoras, N., Letey, J., 1975. Movement of two nonionic surfactants in wettable and water repellent soils. Soil Science Society of America Proceedings 39 (1), 11-16.

Munkholm, L.J., Kay, B.D., 2002. Effect of water regime on aggregate-tensile strength, rupture energy, and friability. Soil Science Society of America Journal 66 (3), 702-709.

Munkholm, L.J., Schjønning, P., Kay, B.D., 2002. Tensile strength of soil cores in relation to aggregate strength, soil fragmentation and pore characteristics. Soil and Tillage Research 64 (1-2), 125-135.

National Cooperative Soil Survey, 2012. National Cooperative Soil Characterization Database. USDA-Natural Resources Conservation Service, Lincoln, NE. [Online.] Available at http://ncsslabdatamart.sc.egov.usda.gov/querypage.aspx (accessed 17 Mar. 2011; verified 14 May 2012)

Osborn, J.F., Pelishek, R.E., Krammes, J.S., Letey, J., 1964. Soil wettability as a factor in erodibility. Soil Science Society of America Proceedings 28 (2), 294-295.

Perfect, E., Kay, B.D., 1994. Statistical characterization of dry aggregate strength using rupture energy. Soil Science Society of America Journal 58 (6), 1804-1809.

Reszkowska, A., Krümmelbein, J., Peth, S., Horn, R., Zhao, Y., Gan, L., 2011. Influence of grazing on hydraulic and mechanical properties of semiarid steppe soils under different vegetation type in Inner Mongolia, China. Plant and Soil 340 (1), 59-72.

Reynolds, W.D., Topp, G.C., 2007. Soil water desorption and imbibition: tension and pressure techniques, In: Carter, M.R., Gregorich, E.G. (Eds.), Soil Sampling and Methods of Analysis, 2nd ed. CRC Press, Boca Raton, FL, pp. 981-997.

Rogowski, A.S., Moldenhauer, W.C., Kirkham, D., 1968. Rupture parameters of soil aggregates. Soil Science Society of America Proceedings 32, 720-724.

SAS Institute Inc., 2009. SAS online documentation, version 9.2 [CD-ROM]. SAS Institute, Inc., Cary, NC.

Seguel, O., Horn, R., 2006. Structure properties and pore dynamics in aggregate beds due to wetting-drying cycles. Journal of Plant Nutrition and Soil Science 169 (2), 221-232.

Sherrod, L.A., Dunn, G., Peterson, G.A., Kolberg, R.L., 2002. Inorganic carbon analysis by modified pressure-calcimeter method. Soil Science Society of America Journal 66 (1), 299-305.

Shirtcliffe, N.J., McHale, G., Newton, M.I., Pyatt, F.B., Doerr, S.H., 2006. Critical conditions for the wetting of soils. Applied Physics Letters 89 (9) (Art. No. 094101).

Soil Survey Staff, 2010. Keys to soil taxonomy, 11th edition. USDA-Natural Resources Conservation Service, Washington, DC. [Online.] [346 pgs.] Available at http:// soils.usda.gov/technical/classification/tax_keys/ (accessed 17 Mar. 2011; verified 14 May 2012).

Thomas, G.W., 1996. Soil pH and soil acidity. In: Sparks, D.L., Page, A.L., Helmke, P.A., Loeppert, R.H. (Eds.), Methods of Soil Analysis, Part 3. Chemical Methods. SSSA Book Ser. 5. Soil Science Society of America, Inc., Madison, WI, pp. 475-490.

Tisdale, S.L., Nelson, W.L., 1975. Soil Fertility and Fertilizers, 3rd edition. Macmillan Publishing Co., Inc., New York.

Tisdall, J.M., Oades, J.M., 1982. Organic matter and water-stable aggregates in soils. Journal of Soil Science 33 (2), 141-163.

Tormena, C.A., Araujo, M.A., Fidalski, J., Imhoff, S., da Silva, A.P., 2008. Quantification of tensile strength and friability of an oxisol (Acrudox) under no-tillage (in Portuguese). Revista Brasileira de Ciência do Solo 32 (3), 943-952.

Utomo, W.H., Dexter, A.R., 1981. Soil friability. Journal of Soil Science 32 (2), 203-213.

van't Woudt, B.D., 1959. Particle coatings affecting the wettability of soils. Journal of Geophysical Research 64 (2), 263-267.

Watts, C.W., Dexter, A.R., 1998. Soil friability: theory, measurement and the effects of management and organic carbon content. European Journal of Soil Science 49 (1), 73-84.

Watts, C.W., Dexter, A.R., Longstaff, D.J., 1996. An assessment of the vulnerability of soil structure to destabilisation during tillage: Part II. Field trials. Soil and Tillage Research 37 (2-3), 175-190. 